\title{
Neuropathic Pain and Itch Mechanisms Underlying Allergic Conjunctivitis
}

\author{
Kuruvilla M, Kalangara J, Eun-Hyung Lee $F$ \\ Emory University, Atlanta, USA \\ J Investig Allergol Clin Immunol 2019; Vol. 29(5): 349-356 \\ doi: 10.18176/jiaci.0320
}

\begin{abstract}
Objective: Among the constellation of symptoms that characterizes allergic conjunctivitis, many (eg, burning and stinging) can be attributed to chronic neuropathic pain. Cumulative data support that these hallmark symptoms might be linked to the effects of allergen-induced neuromodulation. This review investigates the key characteristics of neuropathic itch and pain in allergic conjunctivitis and their underlying pathogenic mechanisms.

Methods: A literature review was conducted using a PubMed search focusing on allergic conjunctivitis, neurogenic inflammation, neuropathic itch, and neuropathic pain. Articles were reviewed, and those discussing clinical course, pathophysiology, and neuronal regulation of chronic neuropathic symptoms as related to allergic disease were summarized.

Results: Recent evidence suggests that some symptoms of allergic conjunctivitis may be better represented as a chronic neuropathic disorder. We found that neurogenic mechanisms may have a significant role in chronic ocular surface inflammation from allergic inflammation. Manifestations may be associated with repeated ocular sensory nerve injury leading to an acute-to-chronic transition, which is in turn associated with neuropathologic changes (peripheral and central sensitization), neuronal dysfunction, and spontaneous ocular pain. Conclusion: Current goals in the management of allergic conjunctivitis aim to minimize the inflammatory cascade associated with the allergic response in the initial stages of the pathogenic mechanism. Based on the mechanistic data reviewed herein, the recognition that neuronal inflammation explains many of the symptoms in allergic conjunctivitis opens new frontiers for drug discovery.
\end{abstract}

Key words: Allergic conjunctivitis. Neuropathic pain. Neuronal dysfunction. Dry eye. Sensitization. Transient receptor potential vanilloid 1 (TRPV1). Transient receptor potential ankyrin 1 (TRPA1). Substance P (SP). Nerve growth factor (NGF).

\section{Resumen}

Objetivo: Entre la constelación de síntomas que caracteriza la conjuntivitis alérgica, muchos, como la sensación de ardor y escozor, pueden ser fundamentados en el dolor neuropático crónico. Cada vez disponemos de más datos para respaldar que estos síntomas característicos podrían estar relacionados con los efectos de la neuromodulación inducida por alérgenos. En esta revisión se enfatizarán las características clave del dolor y el prurito neuropático en la conjuntivitis alérgica y sus mecanismos patológicos.

Métodos: Se realizó una revisión de la literatura realizando una búsqueda bibliográfica en la base PubMed utilizando, como palabras clave, conjuntivitis alérgica, inflamación neurogénica, prurito neuropático, dolor neuropático. Se revisaron los artículos y se resumieron aquellos que se centraban en el curso clínico, la fisiopatología y la regulación neuronal de los síntomas neuropáticos crónicos en relación con la enfermedad alérgica.

Resultados: La literatura científica reciente sugiere que algunos síntomas de la conjuntivitis alérgica se representan mejor como un trastorno neuropático crónico. Los mecanismos neurogénicos parecen tener un papel significativo en la inflamación crónica de la superficie ocular inducida por las reacciones alérgicas. Las manifestaciones pueden estar asociadas con la lesión del nervio sensorial ocular repetida que conlleva una transición de aguda a crónica y se asocia con cambios neuropatológicos (sensibilización periférica y central), disfunción neuronal y dolor ocular espontáneo.

Conclusión: Los objetivos actuales de manejo de la conjuntivitis alérgica se centran en minimizar la cascada inflamatoria asociada con la respuesta alérgica en los estadíos iniciales fisiopatológicos. Sin embargo, y en relación con los datos mecanísticos revisados en este documento, el reconocimiento de que la inflamación neuronal explica muchos de los síntomas en la conjuntivitis alérgica abre nuevas fronteras para el descubrimiento de nuevas opciones terapéuticas.

Palabras clave: Conjuntivitis alérgica. Dolor neuropático. Disfunción neuronal. Ojo seco. Sensibilización. Receptor de potencial transitorio vaniloide 1 (TRPV1). Receptor de potencial transitorio anquirina 1 (TRPA1). Sustancia P (SP). Factor de crecimiento neuronal (NGF). 


\section{Background}

A recent hypothesis has implicated neuronal inflammation as a novel mechanism in the pathogenesis of allergy. Several allergy symptoms, including rhinorrhea, nasal congestion, and cough, are a direct consequence of nervous system alterations [1]. Allergic inflammation can trigger complex neurogenic signaling mechanisms to manifest as neuropathic itch. Neuropathic itch is a chronic condition caused by neuronal dysregulation that typically presents with pruritus but can also present with characteristic neuropathic pain symptoms such as burning and stinging. This differentiates it from classic itch in inflammatory skin diseases, as neuropathic itch is often described as burning in quality. Although pain is not typically considered a significant symptom in allergic conditions, it is a common feature of allergic conjunctivitis (AC). Sensations of irritation and pain of varying intensity frequently accompany AC, including burning, dryness, and grittiness. Neuronal mechanisms underlying these sensations of irritation, discomfort, and itch have yet to be investigated. Delineation of the molecular pathways underlying neuronal inflammation in AC may play a key role in identifying potential therapeutic targets.

\section{Methods}

A comprehensive literature review was performed using a PubMed search with the following terms (in order of relevance): allergic conjunctivitis, neurogenic inflammation, neuropathic itch, neuropathic pain, substance $P(S P)$, calcitonin-gene related peptide (CGRP), nerve growth factor (NGF), transient receptor potential vanilloid 1 (TRPV1), allergic rhinitis, asthma, chronic cough, and gabapentinoids. All searches were conducted in English back to 2000. Articles were reviewed, and those discussing clinical course, pathophysiology, and neuronal regulation of ocular symptoms as related to chronic allergic conjunctivitis were summarized.

\section{Epidemiologic, Pathophysiologic, and Clinical Aspects of AC}

\section{Prevalence and Impact}

Epidemiological data on AC are scarce, likely due to underdiagnosis and the fact that this disease is often linked with allergic rhinitis (AR). It is estimated that $20 \%$ of the US population reports ocular symptoms consistent with AC [2], and approximately $70 \%-80 \%$ of seasonal AR patients have severe ocular symptoms [3]. Ocular symptoms were as severe or more severe than nasal symptoms in approximately $70 \%$ of over 500 hay fever patients in one study [4]. In another recent survey, over $50 \%$ of nasal allergy patients stated that AC symptoms were moderately to extremely bothersome, and for $15 \%$ of these patients, the ocular component of their reactions was the most troublesome [5]. The underlying mechanisms of $\mathrm{AC}$ warrant further investigation.

Seasonal AC and perennial AC, which are the most common forms and the benign end of the spectrum of ocular allergy, are increasing in prevalence [6]. Vernal keratoconjunctivitis and atopic keratoconjunctivitis represent only $2 \%$ of ocular allergy cases, yet are even more severe and have a greater impact on quality of life.

\section{Pathophysiology}

Since the discovery of 2 functionally distinct $\mathrm{CD}^{+}$ T-cell subpopulations $\left(\mathrm{T}_{\mathrm{H}} 1\right.$ and $\left.\mathrm{T}_{\mathrm{H}} 2\right)$ about 30 years ago, it quickly became evident that $\mathrm{T}_{\mathrm{H}} 2$ cells play a crucial role in the development of allergic airway inflammation. It has been commonly assumed that a $\mathrm{T}_{\mathrm{H}} 2$ immune response and type I hypersensitivity form the basis of AC. The allergic response is elicited by ocular exposure to an allergen, such as pollen, that cross-links membrane-bound IgE and triggers mast cell degranulation. This releases a cascade of mediators including histamine, leukotrienes, proteases, prostaglandins, and cytokines. The main contributors to the severity of AC are thought to be the allergen load on the ocular surface and locally produced specific IgE. Furthermore, there is a highly significant correlation between the presence of allergenspecific IgE in tears and ocular allergy symptoms [7]. This continued histamine release, along with increasing allergen load, leads to an expanding population of resident mast cells in conjunctival tissue, thus perpetuating the allergic response [8].

With seasonal $\mathrm{AC}$, the immediate response is predominantly mast cell-mediated. However, little is known about the pathogenesis of the late phase allergic reaction corresponding to the persistent clinical inflammation that typifies ocular signs and symptoms in chronic allergic diseases. Vernal keratoconjunctivitis and atopic keratoconjunctivitis in particular are characterized by a severe late-phase reaction comprising mucosal infiltration by eosinophils, neutrophils, basophils, and T lymphocytes. Mediators released by conjunctival mast cells during the early-phase reactions also contribute to the development of late-phase inflammation during IgE-mediated AC in vivo. There is a general correlation between the degree of cellular infiltration and the severity of disease. Moreover, products from infiltrating cells are known to promote conjunctival irritation. In addition, conjunctival and corneal epithelial cells and fibroblasts mount the allergic response by producing cytokines and other factors that maintain local inflammation and lead to tissue remodeling.

\section{Clinical Manifestations}

Ocular symptoms of AC are frequently underreported. The pathognomonic symptoms of ocular allergy include itching, tearing, and conjunctival and eyelid swelling and redness. These are reflected in the Total Ocular Symptom Score questionnaire, which is used to measure symptoms of AC. However, AC patients have multiple distinguishing symptoms beyond itch including grittiness, burning and stinging (65\%), and soreness (75\%) [9]. They may also complain of a foreign body sensation, blurring, and photophobia if there is corneal involvement. Conjunctival hyperemia and papillae on the tarsal conjunctiva may be observed on examination. Local symptoms are often 
accompanied by irritability and fatigue [3] and patients with $\mathrm{AC}$ have a poor quality of life, irrespective of the severity of associated nasal symptoms [10].

Neuronal dysregulation is likely to be responsible for at least some of these symptoms. Exaggerated hyperreactivity to nonspecific stimuli such as temperature changes, strong odors, and irritants is known to be a manifestation of neuronal inflammation in nonallergic and mixed rhinitis [11]. This is akin to hyperreactivity to heat, sunlight, and wind during the active phase of vernal keratoconjunctivitis, which may be reflective of neural involvement [12], as is the nonspecific increase in reactivity in the conjunctival response to histamine in $\mathrm{AC}$ patients [13]. In addition, exposure to nonspecific environmental stimuli, pollutants, and cigarette smoke were reported to be triggers in a substantial proportion of AC patients [14] and may be similarly attributable to neural hypersensitivity. The term vasomotor conjunctivitis has been used to describe this phenomenon [15].

\section{Mechanisms of AC-Induced Neuropathic Pain}

\section{Sensory Nociceptive Innervation of the Ocular Surface}

Peripheral origin: The ocular surface is innervated by primary sensory neurons located in the trigeminal ganglion, most of which $(70 \%)$ are polymodal nociceptors [16]. The afferent $\mathrm{C}$ fibers express transient receptor potential (TRP) channels that play a role in many diseases. Pain and itch also employ largely overlapping transduction machinery. Transient receptor potential vanilloid 1 (TRPV1) and transient receptor potential ankyrin 1 (TRPA1) are 2 such TRP channels that appear to be important in allergic responses. TRPV1 is known as a capsaicin responder, but also reacts to a host of other proinflammatory exogenous and endogenous agents. In addition, it is stimulated by several mediators that are relevant to the allergic reaction, such as histamine and bradykinin. As with TRPV1, TRPA1 is activated by inflammatory mediators including those involved in allergic disease.

TRPV1/TRPA1 receptor activation in the eye induces the release of neuropeptides such as neurokinins, calcitonin generelated peptide (CGRP), and substance P (SP). Furthermore, activated sensory neurons can themselves directly release proinflammatory peptides into surrounding tissue (antidromic release). Other molecules known as neurotrophins (eg, nerve growth factor [NGF]), act directly on peptidergic $\mathrm{C}$ fiber nociceptors to potentiate TRPV1 receptors and increase the expression of substance P and TRPV1. This ultimately translates into nociception and pain [16].

Central representation: The cell bodies of sensory neurons innervating the ocular surface are located in the trigeminal ganglion and terminate in the trigeminal brainstem complex. There, they establish contact with second-order ocular neurons that project to the somatosensory cortex, where the original noxious signal is perceived as pain.

A schematic representation of the pathogenesis of ocular pain and itch is outlined in Figure 1.

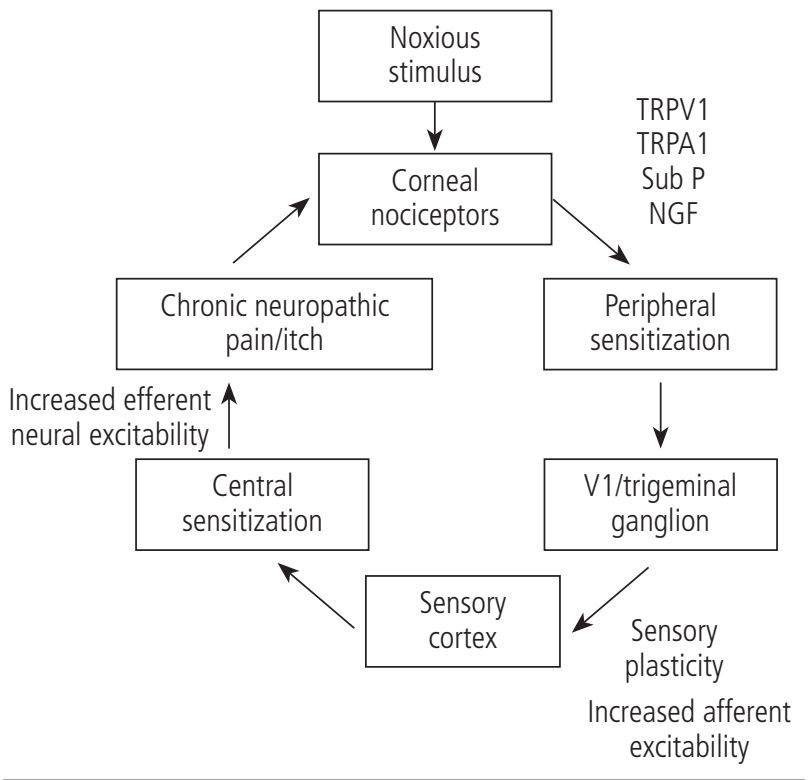

Figure 1. Schematic representation of neuropathic pain and itch in ocular surface disease.

\section{Allergen-Induced Neuromodulation of Sensory Nerves}

Under pathological and chronic conditions, dysfunction of the nervous system itself can generate chronic neuropathic pain and itch. This is secondary to neural plastic changes in primary sensory neurons of the peripheral nervous system (peripheral sensitization) and spinal cord, brainstem, and cortical neurons in the central nervous system (central sensitization). A significant body of physiological data suggests that allergy symptoms may be significantly modulated by the nervous system. This neural plasticity may be responsible for symptoms of neuropathic pain and itch in AC. Reflex neural activity is upregulated in the presence of allergic inflammation and further amplifies the histamine-mediated immunopathological response in the conjunctiva.

Peripheral sensitization in allergic inflammation: During chronic inflammation, including allergic inflammation, longlasting changes develop in the expression and function of stimulus-transducing ion channels such as TRPV1 and TRPA1. This results in abnormal hyperexcitability of neurons and may evoke chronic neuropathic pain.

TRPV1 is believed to be a major cause of neuropathic pain [17]. It also has a proven role in itch and, in particular, histamine-induced itch. Chronic allergic inflammation is known to mediate plasticity of TRPV1 in airway diseases. Inhalation of allergen by rats or guinea pigs leads to the expression of TRPV1 in A $\delta$ cough nerves [18]. TRPV1 expression and substance P levels were found to be significantly higher in patients with nonallergic rhinitis [19] and asthma, especially refractory cases [20]. Furthermore, histamine sensitizes the nociceptor TRPV1 and has been shown to contribute to visceral hypersensitivity in animals [21]. In addition, other endogenous inflammatory allergy mediators such as prostaglandin E2 and bradykinin can markedly enhance the sensitivity of TRPV1 and lower its threshold for activation of sensory nerves [22]. 
Inhalation of allergen also upregulates the expression of genes involved in the production of substance $\mathrm{P}$ and CGRP, both of which act as itch sensation-enhancing neuropeptides [23,24]. Allergen exposure also enhances the release of substance $\mathrm{P}$ and CGRP from sensory nerve endings (antidromic pathway). Substance P and CGRP cause antidromic stimulation of nociceptive fibers, which results in $\mathrm{C}$-fiber activation and synergistically augments the allergic inflammatory reaction [24,25]. In 2017, Azimi et al [26] described the role of substance $\mathrm{P}$-mediated activation of $\mathrm{MC}$ receptors in inducing itching in a mouse model.

Allergic reactions can also lead directly to the release of neurotrophic factors, especially NGF, from mast cells and other cells, such as the airway epithelium [27]. NGF is a complex regulator of neural plasticity that further sensitizes afferent nerves. It has been found in eosinophils and peripheral nerves $[25,28]$ and is upregulated by nasal allergen provocation. Endogenous NGF levels are elevated not only in certain chronic pain conditions, but NGF serum levels have also been found to be increased in allergic diseases and asthma [29], as well as in bronchioalveolar lavage and nasal lavage fluids from these patients.

All of these factors further stimulate the vascular endothelial cells or mast cells to release even more chemical mediators such as histamine, thus producing a vicious circle of disease exacerbation.

This concept of peripheral sensitization was supported by a guinea pig model of $\mathrm{AC}$, which demonstrated a reduced threshold for activation of polymodal nociceptors, as well as an augmented response to noxious chemical stimuli. The authors suggested the operation of a comparable pathway in humans. The overall changes in firing of corneal sensory fibers correlate with the foreign body and itching sensations reported by $\mathrm{AC}$ patients [30], thus suggesting a possible TRPV1-dependent pathway in the sensitization stage. However, further studies must be performed to confirm this finding.

The sensitization of sensory nerves results in augmented pain sensations and may be responsible for the burning quality of $\mathrm{AC}$ symptoms. Chronic inflammation may also damage sensory nerve fibers of the ocular surface leading to formation of neuromas that spontaneously discharge and cause unpleasant sensations, such as pain, dryness, and grittiness [16].

Central sensitization in allergic inflammation: Neuropathic pain may also result from abnormal function of higher brain structures, from where ocular trigeminal ganglion neurons project. Amplification of responses occur in the central nervous system through sensitization of central pathways, failure of inhibitory control mechanisms, or both. Central sensitization can cause secondary hyperalgesia and allodynia, thus contributing to enhanced inflammatory pain.

Central neural mechanisms are also thought to be involved in allergic inflammation. Extended exposure to allergen in a primate model of allergic asthma causes phenotypic changes in the intrinsic membrane properties of central nervous system neurons, resulting in their increased excitability [31]. This is analogous to the increased excitability of spinal neurons during prolonged neuropathic or inflammatory pain.

Other consequences of central sensitization include changes in autonomic nerve activity. Allergic inflammation may enhance autonomic tone, which has been directly observed in an allergen-sensitized guinea pig model [32].

Loss of inhibitory synaptic transmission (disinhibition) in the spinal cord has also been attributed to both chronic pain and chronic itch. This disinhibition of the central nervous system and, therefore, hyperactivity of trigeminal nociceptive pathways can produce a much more intense response to irritants.

Taken together, the evidence supports a model in which allergic inflammation leads to the release of proinflammatory mediators that sensitize trigeminal sensory neurons (and their processes), resulting in a decreased pain/itch threshold. This may manifest as neuropathic pain and itch. Therefore, there is a putative positive feedback loop between allergic cells and neuronal inflammation in the development and maintenance of the pathophysiology of AC. These, in turn, modulate ocular responses to allergic and nonallergic stimuli, thus translating the degree of inflammation into severity of neural hyperreactivity.

Figure 2 outlines neural involvement in allergic conjunctivitis.

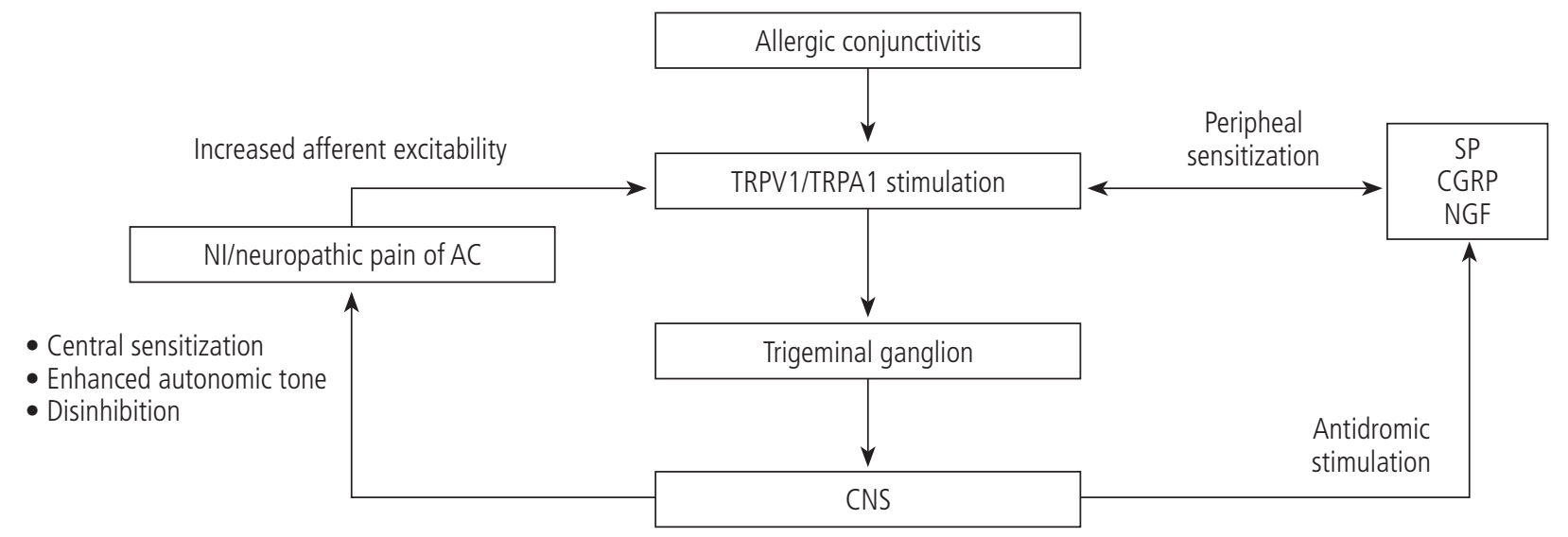

Figure 2. Schematic representation of neural sensitization in allergic conjunctivitis. AC indicates allergic conjunctivitis; TRPV, transient receptor potential vanilloid; TRPA, transient receptor potential ankyrin; SP, substance P; CGRP, calcitonin gene-related peptide; NGF, nerve growth factor. 


\section{Ocular Symptoms Deriving From Neurogenic Inflammation}

The importance of neurogenic inflammation is suggested by the large trigeminal sensory innervation of the ocular surface. Mast cell activation in AC results in overt stimulation of polymodal nociceptors, which are responsible for burning and stinging eye pain. Nasal provocation studies in AR patients showed that TRPV1 and TRPA1 activators induced immediate and more prolonged pain; during the pollen season, provocations with TRPV1 activators induced itch as well as pain [33]. In fact, in a recent series, $80 \%$ of patients with symptomatic AC had no evidence of conjunctival inflammation, while over half had nasal inflammation only. It was postulated that neurogenic mediators could explain this disconnect between ocular symptoms (especially itching) and detectable inflammatory conjunctival infiltration [34].

Emerging evidence suggests that the underlying allergic and neural inflammatory pathways can interact. Histamineinduced itching via $\mathrm{H} 1$ receptors on conjunctival sensory nerve fibers requires activation of TRPV1. Histamine-independent pruritic pathways, as in IL-31-induced itch, also directly activate TRPV1/TRPA1 sensory nerves in mouse models of dermatitis [35]. Furthermore, leukotriene B4 (LTB4) can activate TRPV1 and induce itching via interaction with LTB4 receptors on sensory nerves [36].

The activation of TRPV1 causes the release of proinflammatory and pruritic mediators. It has been reported that substance $\mathrm{P}$ levels are increased in tears of patients with AC compared with healthy individuals, suggesting that substance $\mathrm{P}$ may contribute to the pathogenesis and severity of AC [37]. The concentration of substance $\mathrm{P}$ in tears has also been found to be elevated at baseline in patients with seasonal $\mathrm{AC}$ and vernal keratoconjunctivitis [38], with further increases in substance $\mathrm{P}$ and CGRP documented after conjunctival allergen challenge [39]. On the ocular surface, NGF has been hypothesized to influence the immune response in AC [40].

A strong relationship has long been recognized between $\mathrm{AC}$ and dry eye, with a large symptomatic crossover that may reflect interrelated mechanistic characteristics [41]. Tear film instability, a characteristic of dry eye, was also noted to be more pronounced in children with AC [42]. Increased inflammatory allergic cytokines are also associated with goblet cell loss and tear volume insufficiency. Recent evidence has further expanded the phenotypic spectrum of patients with dry eye syndrome and implicated neuropathic pain in dry eye pathogenesis. A significant body of physiological data suggests that dry eye symptoms may be significantly modulated by the nervous system [43]. However, our understanding of neuropathic pain in dry eye remains incomplete, largely because of limited access to tests that assess the function of the ocular sensory-nociceptive apparatus.

\section{Neurogenic Mechanisms of AC: Implications for Management Approaches}

The current mainstay of AC therapy includes topical mast cell stabilizers and antihistamines, with variable and limited clinical success possibly because factors other than mast cells and histamine play important roles in AC. Therefore, research into more effective treatments is necessary. The simultaneous targeting of multiple inflammatory signaling mediators might represent a more promising treatment modality.

Addressing the neurogenic component of allergic inflammation has been an active area of study. The hyperreactivity phenotype of allergic sensitization can be physiologically dissociated from the immune component, and neural sensitization has been targeted in animal models as well as in humans.

Murine models of allergic sensitization have provided evidence of the anti-inflammatory actions induced by the depletion of neuropeptides [25]. Mice that had undergone surgical denervation of cutaneous sensory nerves demonstrated dampened inflammatory responses after induction of anaphylaxis and mast cell activation. Similar responses were obtained following pretreatment with selective substance P and CGRP antagonists [44]. Recently, treatment with olopatadine and naphazoline hydrochloride was shown to reduce conjunctivitis in mice via effects on NGF [45].

A prominent candidate pathway is TRPV1, which has been described in several forms of allergic disease. Vagal sensory neurons in TRPV1 can dramatically affect airway hyperreactivity. Several trials have explored therapies that target TRPV1-expressing neurons as a strategy for the management of allergic diseases. This has been supported by murine models, where ablation of TRPV1 expressing vagal neurons abolishes airway hyperreactivity, even in the presence of a full lung inflammatory response [46]. In yet another mouse model, the use of a TRPV1 antagonist alleviated atopic dermatitis-like symptoms as evidenced by suppression of itch behavior and acceleration of skin barrier recovery [47]. In another murine model of AC, ocular itch was significantly attenuated in TRPA 1 and TRPV1 knockout mice, implicating both TRPA1 and TRPV1 in the genesis of allergic ocular itch [48].

Clinical trials exploring the potential for neuronal-targeted therapies in patients with allergic inflammation are in their early stages. However, in subjects with allergic rhinitis, an intranasal TRPV1 antagonist alone or combined with fluticasone propionate did not improve allergen-induced symptoms [49]. Similarly, symptoms appearing after exposure to cold dry air in patients with nonallergic rhinitis did not Improve with this therapy [50].

These findings may indicate that TRPV1 may be a facilitating ion channel-but not a key mediator-for itch and other allergic symptoms, suggesting that other receptors expressed in C fibers, such as TRPA1, might be involved in their development.

On the other hand, a recent study of patients with nonallergic rhinitis revealed overexpression of TRPV1 in the nasal mucosa and increased substance P levels in nasal secretions at baseline, with reduced symptoms and reduced levels of nasal hyperreactivity following topical capsaicin treatment [19]. The authors suggest that the ablation of the TRPV1-substance P nociceptive signaling pathway 
Table. Randomized Controlled Trials of Neuropathic Therapies for Allergic/Nonallergic Airway Inflammation

\begin{tabular}{|c|c|c|c|c|}
\hline Drug & Mechanism & Disease Evaluated & Outcome Assessed & Efficacy \\
\hline SB-705498 & $\begin{array}{l}\text { Intranasal TRPV1 } \\
\text { antagonist }\end{array}$ & $\begin{array}{l}\text { Allergic } \\
\text { rhinitis }\end{array}$ & $\begin{array}{l}\text { Total nasal symptom score } \\
\text { (TNSS) - SB-705498 versus } \\
\text { placebo, fluticasone } \\
\text { propionate (FP), } \\
\text { and SB-705498 + FP }\end{array}$ & $\begin{array}{c}\text { No differences in allergen-induced } \\
\text { mean TNSS between SB-705498 } \\
\text { alone and placebo or between } \\
\text { SB-705498 plus FP and FP } \\
\text { alone [49] }\end{array}$ \\
\hline SB-705498 & $\begin{array}{l}\text { Intranasal TRPV1 } \\
\text { antagonist }\end{array}$ & $\begin{array}{l}\text { Nonallergic } \\
\text { rhinitis }\end{array}$ & $\begin{array}{c}\text { Total symptom score (TSS), } \\
\text { expressed as weighted mean } \\
\text { over } 60 \text { minutes (WM0-60) } \\
\text { or maximum TSS at } 1 \text { hour and } \\
24 \text { hours postdosing }\end{array}$ & $\begin{array}{l}\text { No differences in or maximum } \\
\text { TSS at } 1 \text { hour and } 24 \text { hours } \\
\text { postdosing on days } 1 \text { or } 14 \text {, } \\
\text { relative to placebo [50] }\end{array}$ \\
\hline Capsaicin & $\begin{array}{l}\text { Intranasal TRPV1 } \\
\text { agonist that ablates } \\
\text { the TRPV1-SP } \\
\text { signaling pathway }\end{array}$ & $\begin{array}{l}\text { Idiopathic } \\
\text { rhinitis }\end{array}$ & $\begin{array}{l}\text { Visual analog scale (VAS) and } \\
\text { therapeutic response evaluation (TRE) } \\
\text { scores, and nasal hyperreactivity by means } \\
\text { of cold dry air (CDA) provocation }\end{array}$ & $\begin{array}{c}\text { Significant decrease in VAS } \\
\text { and TRE scores, and abrogation } \\
\text { of nasal hyperreactivity } \\
\text { to CDA [19] }\end{array}$ \\
\hline Capsaicin & $\begin{array}{l}\text { Intranasal TRPV1 } \\
\text { agonist that ablates } \\
\text { the TRPV1-SP } \\
\text { signaling pathway }\end{array}$ & $\begin{array}{l}\text { Nonallergic } \\
\text { rhinitis }\end{array}$ & $\begin{array}{l}\text { Visual analog scale (VAS) scores, } \\
\text { and nasal hyperreactivity } \\
\text { by means of CDA provocation }\end{array}$ & $\begin{array}{l}\text { Significant decrease in VAS scores, } \\
\text { and abrogation of nasal } \\
\text { hyperreactivity to CDA up } \\
\text { to } 9 \text { months after treatment [53] }\end{array}$ \\
\hline $\begin{array}{l}\text { ICX72 } \\
\text { (capsicum + } \\
\text { eucalyptol) }\end{array}$ & $\begin{array}{l}\text { Intranasal TRPV1 } \\
\text { agonist that ablates } \\
\text { the TRPV1-SP } \\
\text { signaling pathway }\end{array}$ & $\begin{array}{l}\text { Nonallergic } \\
\text { rhinitis }\end{array}$ & $\begin{array}{c}\text { Total nasal symptom scores (TNSS), } \\
\text { individual symptom scores (ISS) } \\
\text { over } 2 \text { weeks and average time } \\
\text { to first relief }\end{array}$ & $\begin{array}{l}\text { Significant improvements in TNSS } \\
\text { and each ISS, and average time to } \\
\text { first relief of } 52.6 \text { seconds [51] }\end{array}$ \\
\hline
\end{tabular}

by capsaicin in the nasal mucosa was responsible for this therapeutic effect. Several trials of topical capsaicin in patients with nonallergic rhinitis have demonstrated relief of symptoms and nasal hyperreactivity [51-53].

Systemic neuromodulating agents may constitute another approach to the management of neuropathic symptoms in allergic disease. With the recognition that chronic cough is similar to other hypersensitivity neuropathic syndromes such as chronic pain [54], gabapentin, a common treatment for neuropathic pain, has proven clearly efficacious for refractory cough [55]. The clinical relevance of neuroinflammation and sensitization has also been extrapolated to chronic itch. Cevikbas et al [56] described a synergistic role for $\gamma$-aminobutyric acid $\mathrm{A}$ and $\mathrm{B}$ agonists for addressing symptoms of itching in murine atopic dermatitis. The utility of gabapentin has also been demonstrated in this setting [57].

The Table summarizes trials examining neuromodulation to date for allergic and nonallergic upper airway diseases presumed to be related to neuroplasticity.

\section{Future Directions}

Despite substantial advances in our understanding of the pathophysiology of AC, the exact association between targeted therapy and successful responses remains controversial and prevents these findings being applied in clinical practice. However, targeting neuronal inflammation remains a potential novel strategy for the treatment of AC. The definition of these pain-relevant neural circuits may facilitate future development of targeted therapies.

\section{Conclusions}

Among the constellation of symptoms that characterizes $\mathrm{AC}$, many, such as burning and stinging, can be attributed to chronic neuropathic pain. There is evidence to support that these hallmark symptoms might be linked to the effects of allergeninduced neuromodulation. Thus, neurogenic mechanisms may have a significant role in chronic ocular surface inflammation. Current management goals in allergic conjunctivitis aim to minimize the inflammatory cascade associated with allergic response in the early stages of the pathogenic mechanism. Based on the mechanistic data reviewed herein, the recognition that neuronal inflammation explains many of the symptoms in $\mathrm{AC}$ opens new frontiers for drug discovery.

\section{Funding}

The authors declare that no funding was received for the present study.

\section{Conflicts of Interest}

The authors declare that they have no conflicts of interest.

\section{References}

1. Undem BJ, Taylor-Clark T. Mechanisms underlying the neuronal-based symptoms of allergy. J Allergy Clin Immunol. 2014;133(6):1521-34.

2. Gomes PJ. Trends in prevalence and treatment of ocular allergy. Curr Opin Allergy Clin Immunol. 2014;14(5):451-6. 
3. Katelaris $\mathrm{CH}$, Bielory L. Evidence-based study design in ocular allergy trials. Curr Opin Allergy Clin Immunol. 2008;8(5):4848.

4. Wuthrich B, Brignoli $R$, Canevascini $M$, Gerber $M$. Epidemiological survey in hay fever patients: symptom prevalence and severity and influence on patient management. Schweiz Med Wochenschr. 1998;128(5):139-43.

5. Blaiss MS. Allergic rhinoconjunctivitis: burden of disease. Allergy Asthma Proc. 2007;28(4):393-7.

6. Ono SJ, Abelson MB. Allergic conjunctivitis: update on pathophysiology and prospects for future treatment. J Allergy Clin Immunol. 2005;115(1):118-22.

7. Hoffmann-Sommergruber K, Ferreira ED, Ebner C, Barisani $T$, Korninger L, Kraft D, et al. Detection of allergen-specific $\lg \mathrm{E}$ in tears of grass pollen-allergic patients with allergic rhinoconjunctivitis. Clin Exp Allergy. 1996;26(1):79-87.

8. Anderson DF, MacLeod JD, Baddeley SM, Bacon AS, McGill Jl, Holgate ST, et al. Seasonal allergic conjunctivitis is accompanied by increased mast cell numbers in the absence of leucocyte infiltration. Clin Exp Allergy. 1997;27(9):1060-6.

9. Katelaris $\mathrm{CH}$. Ocular allergy in the Asia Pacific region. Asia Pac Allergy. 2011;1(3):108-14.

10. Virchow JC, Kay S, Demoly P, Mullol J, Canonica W, Higgins V. Impact of ocular symptoms on quality of life (QoL), work productivity and resource utilisation in allergic rhinitis patients--an observational, cross sectional study in four countries in Europe. J Med Econ. 2011;14(3):305-14.

11. Bernstein JA, Singh U. Neural Abnormalities in Nonallergic Rhinitis. Curr Allergy Asthma Rep. 2015;15(4):18.

12. Bonini S, Bonini S, Schiavone $M$, Centofanti $M$, Allansmith MR, Bucci MG. Conjunctival hyperresponsiveness to ocular histamine challenge in patients with vernal conjunctivitis. J Allergy Clin Immunol. 1992;89(1 Pt 1):103-7.

13. Ciprandi G, Buscaglia S, Pesce GP, Bagnasco M, Canonica GW. Ocular challenge and hyperresponsiveness to histamine in patients with allergic conjunctivitis. J Allergy Clin Immunol. 1993;91(6):1227-30.

14. Leonardi A, Piliego F, Castegnaro A, Lazzarini D, La Gloria Valerio A, Mattana $P$, et al. Allergic conjunctivitis: a crosssectional study. Clin Exp Allergy. 2015;45(6):1118-25.

15. Bielory L. Vasomotor (perennial chronic) conjunctivitis. Curr Opin Allergy Clin Immunol. 2006;6(5):355-60.

16. Belmonte C, Aracil A, Acosta MC, Luna C, Gallar J. Nerves and sensations from the eye surface. Ocul Surf. 2004;2(4):248-53.

17. Sukhotinsky I, Ben-Dor E, Raber P, Devor M. Key role of the dorsal root ganglion in neuropathic tactile hypersensibility. Eur J Pain. 2004;8(2):135-43.

18. Lieu TM, Myers AC, Meeker S, Undem BJ. TRPV1 induction in airway vagal low-threshold mechanosensory neurons by allergen challenge and neurotrophic factors. Am J Physiol Lung Cell Mol Physiol. 2012;302(9):L941-8.

19. Van Gerven L, Alpizar YA, Wouters MM, Hox V, Hauben $E$, Jorissen $M$, et al. Capsaicin treatment reduces nasal hyperreactivity and transient receptor potential cation channel subfamily V, receptor 1 (TRPV1) overexpression in patients with idiopathic rhinitis. J Allergy Clin Immunol. 2014;133(5):13329, 9 e1-3.

20. McGarvey LP, Butler CA, Stokesberry S, Polley L, McQuaid S, Abdullah $\mathrm{H}$, et al. Increased expression of bronchial epithelial transient receptor potential vanilloid 1 channels in patients with severe asthma. J Allergy Clin Immunol. 2014;133(3):70412 e4.

21. Wouters MM, Balemans D, Van Wanrooy S, Dooley J, CibertGoton V, Alpizar YA, et al. Histamine Receptor H1-Mediated Sensitization of TRPV1 Mediates Visceral Hypersensitivity and Symptoms in Patients With Irritable Bowel Syndrome. Gastroenterology. 2016;150(4):875-87 e9.

22. Raemdonck K, de Alba J, Birrell MA, Grace M, Maher SA, Irvin CG, et al. A role for sensory nerves in the late asthmatic response. Thorax. 2012;67(1):19-25.

23. O'Hanlon S, Facer P, Simpson KD, Sandhu G, Saleh HA, Anand P. Neuronal markers in allergic rhinitis: expression and correlation with sensory testing. Laryngoscope. 2007;117(9):1519-27.

24. Sarin S, Undem B, Sanico A, Togias A. The role of the nervous system in rhinitis. J Allergy Clin Immunol. 2006;118(5):9991016.

25. Rogerio AP, Andrade EL, Calixto JB. C-fibers, but not the transient potential receptor vanilloid 1 (TRPV1), play a role in experimental allergic airway inflammation. Eur J Pharmacol. 2011;662(1-3):55-62

26. Azimi E, Reddy VB, Pereira PJS, Talbot S, Woolf CJ, Lerner EA Substance $P$ activates Mas-related $G$ protein-coupled receptors to induce itch. J Allergy Clin Immunol. 2017;140(2):447-53 e3.

27. Bresciani M, Laliberte F, Laliberte MF, Gramiccioni C, Bonini S Nerve growth factor localization in the nasal mucosa of patients with persistent allergic rhinitis. Allergy. 2009;64(1):112-7.

28. Raap U, Braunstahl GJ. The role of neurotrophins in the pathophysiology of allergic rhinitis. Curr Opin Allergy Clin Immunol. 2010;10(1):8-13.

29. Bonini S, Lambiase A, Bonini S, Angelucci F, Magrini L, Manni $L$, et al. Circulating nerve growth factor levels are increased in humans with allergic diseases and asthma. Proc Natl Acad Sci U S A. 1996;93(20):10955-60.

30. Acosta MC, Luna C, Quirce S, Belmonte C, Gallar J. Changes in sensory activity of ocular surface sensory nerves during allergic keratoconjunctivitis. Pain. 2013:154(11):2353-62.

31. Chen CY, Bonham AC, Schelegle ES, Gershwin LJ, Plopper CG, Joad JP. Extended allergen exposure in asthmatic monkeys induces neuroplasticity in nucleus tractus solitarius. J Allergy Clin Immunol. 2001;108(4):557-62.

32. Undem BJ, Hubbard WC, Christian EP, Weinreich D. Mast cells in the guinea pig superior cervical ganglion: a functional and histological assessment. J Auton Nerv Syst. 1990;30(1):75-87.

33. Alenmyr L, Hogestatt ED, Zygmunt PM, Greiff L. TRPV1mediated itch in seasonal allergic rhinitis. Allergy. 2009;64(5):807-10.

34. Gelardi M, Leo ME, Quaranta VN, Iannuzzi L, Tripodi S, Quaranta $N$, et al. Clinical characteristics associated with conjunctival inflammation in allergic rhinoconjunctivitis. J Allergy Clin Immunol Pract. 2015;3(3):387-91 e1.

35. Cevikbas F, Wang X, Akiyama T, Kempkes C, Savinko T, Antal A, et al. A sensory neuron-expressed IL-31 receptor mediates T helper cell-dependent itch: Involvement of TRPV1 and TRPA1. J Allergy Clin Immunol. 2014;133(2):448-60.

36. Akiyama T, Carstens E. Neural processing of itch. Neuroscience. 2013;250:697-714.

37. Mantelli F, Micera A, Sacchetti M, Bonini S. Neurogenic inflammation of the ocular surface. Curr Opin Allergy Clin Immunol. 2010;10(5):498-504. 
38. Micera A, Lambiase A, Bonini S. The role of neuromediators in ocular allergy. Curr Opin Allergy Clin Immunol. 2008;8(5):466-71.

39. Sacchetti M, Micera A, Lambiase A, Speranza S, Mantelli F, Petrachi $G$, et al. Tear levels of neuropeptides increase after specific allergen challenge in allergic conjunctivitis. Mol Vis. 2011;17:47-52.

40. Lambiase A, Bonini S, Micera A, Rama P, Bonini S, Aloe L. Expression of nerve growth factor receptors on the ocular surface in healthy subjects and during manifestation of inflammatory diseases. Invest Ophthalmol Vis Sci. 1998;39(7):1272-5.

41. Bielory L. Ocular allergy and dry eye syndrome. Curr Opin Allergy Clin Immunol. 2004;4(5):421-4.

42. Dogru M, Gunay M, Celik G, Aktas A. Evaluation of the tear film instability in children with allergic diseases. Cutan Ocul Toxicol. 2016;35(1):49-52.

43. Kalangara JP, Galor A, Levitt RC, Felix ER, Alegret $R$, Sarantopoulos CD. Burning Eye Syndrome: Do Neuropathic Pain Mechanisms Underlie Chronic Dry Eye? Pain Med. 2016;17(4):746-55.

44. Siebenhaar F, Magerl M, Peters EM, Hendrix S, Metz $M$, Maurer M. Mast cell-driven skin inflammation is impaired in the absence of sensory nerves. J Allergy Clin Immunol. 2008;121(4):955-61.

45. Quan L, He H. Treatment with olopatadine and naphazoline hydrochloride reduces allergic conjunctivitis in mice through alterations in inflammation, NGF and VEGF. Mol Med Rep. 2016;13(4):3319-25.

46. Trankner D, Hahne N, Sugino K, Hoon MA, Zuker C. Population of sensory neurons essential for asthmatic hyperreactivity of inflamed airways. Proc Natl Acad Sci U S A. 2014;111(31):11515-20.

47. Yun JW, Seo JA, Jeong YS, Bae IH, Jang WH, Lee J, et al. TRPV1 antagonist can suppress the atopic dermatitis-like symptoms by accelerating skin barrier recovery. J Dermatol Sci. 2011;62(1):8-15.

48. Huang CC, Kim YS, Olson WP, Li F, Guo C, Luo W, et al. A histamine-independent itch pathway is required for allergic ocular itch. J Allergy Clin Immunol. 2016;137(4):1267-70 e6.

49. Bareille P, Murdoch RD, Denyer J, Bentley J, Smart K, Yarnall $K$, et al. The effects of a TRPV1 antagonist, SB-705498, in the treatment of seasonal allergic rhinitis. Int J Clin Pharmacol Ther. 2013;51(7):576-84.
50. Murdoch RD, Bareille P, Denyer J, Newlands A, Bentley J, Smart $K$, et al. TRPV1 inhibition does not prevent cold dry air-elicited symptoms in non-allergic rhinitis. Int J Clin Pharmacol Ther. 2014;52(4):267-76.

51. Bernstein JA, Davis BP, Picard JK, Cooper JP, Zheng S, Levin LS. A randomized, double-blind, parallel trial comparing capsaicin nasal spray with placebo in subjects with a significant component of nonallergic rhinitis. Ann Allergy Asthma Immunol. 2011;107(2):171-8.

52. Gevorgyan A, Segboer C, Gorissen R, van Drunen CM, Fokkens W. Capsaicin for non-allergic rhinitis. Cochrane Database Syst Rev. 2015(7):CD010591.

53. Van Rijswijk JB, Boeke EL, Keizer JM, Mulder PG, Blom HM, Fokkens WJ. Intranasal capsaicin reduces nasal hyperreactivity in idiopathic rhinitis: a double-blind randomized application regimen study. Allergy. 2003;58(8):754-61.

54. Morice AH, Faruqi S, Wright CE, Thompson R, Bland JM. Cough hypersensitivity syndrome: a distinct clinical entity. Lung. 2011;189(1):73-9.

55. Ryan NM, Birring SS, Gibson PG. Gabapentin for refractory chronic cough: a randomised, double-blind, placebocontrolled trial. Lancet. 2012;380(9853):1583-9.

56. Cevikbas F, Braz JM, Wang X, Solorzano C, Sulk M, Buhl T, et al. Synergistic antipruritic effects of gamma aminobutyric acid $A$ and $B$ agonists in a mouse model of atopic dermatitis. J Allergy Clin Immunol. 2017;140(2):454-64 e2.

57. Yosipovitch G, Bernhard JD. Clinical practice. Chronic pruritus. N Engl J Med. 2013;368(17):1625-34. Manuscript received June 20, 2018; accepted for
publication September 11, 2018.

\section{- Merin Elizabeth Kuruvilla}

1365 Clifton Rd NE, Bldg A, 3rd Flr

Atlanta, GA-30322

USA

E-mail: merin.ek1@gmail.com 